Journal of Educational Technology

$\&$ Online Learning

Volume 5 | Issue 1 | 2022

http://dergipark.org.tr/jetol

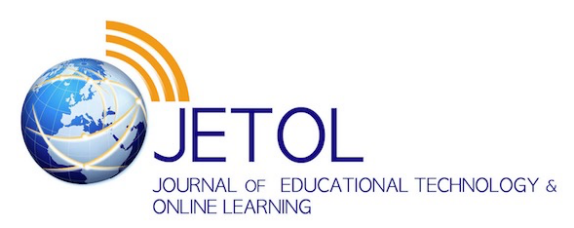

\title{
A digital educational tool experience in history course: Creating digital comics via Pixton Edu
}

\author{
Ayşegül Nihan Erol Şahin ${ }^{\text {a* }}$ (D), Hatice Kara Erol ${ }^{\text {a }}$ (D) \\ a Gazi University, Turkey
}

Suggested citation: Erol Şahin, A. N. \& Kara Erol, H. (2022). A digital educational tool experience in history course: Creating digital comics via Pixton Edu. Journal of Educational Technology \& Online Learning, 5(1), 223-242.

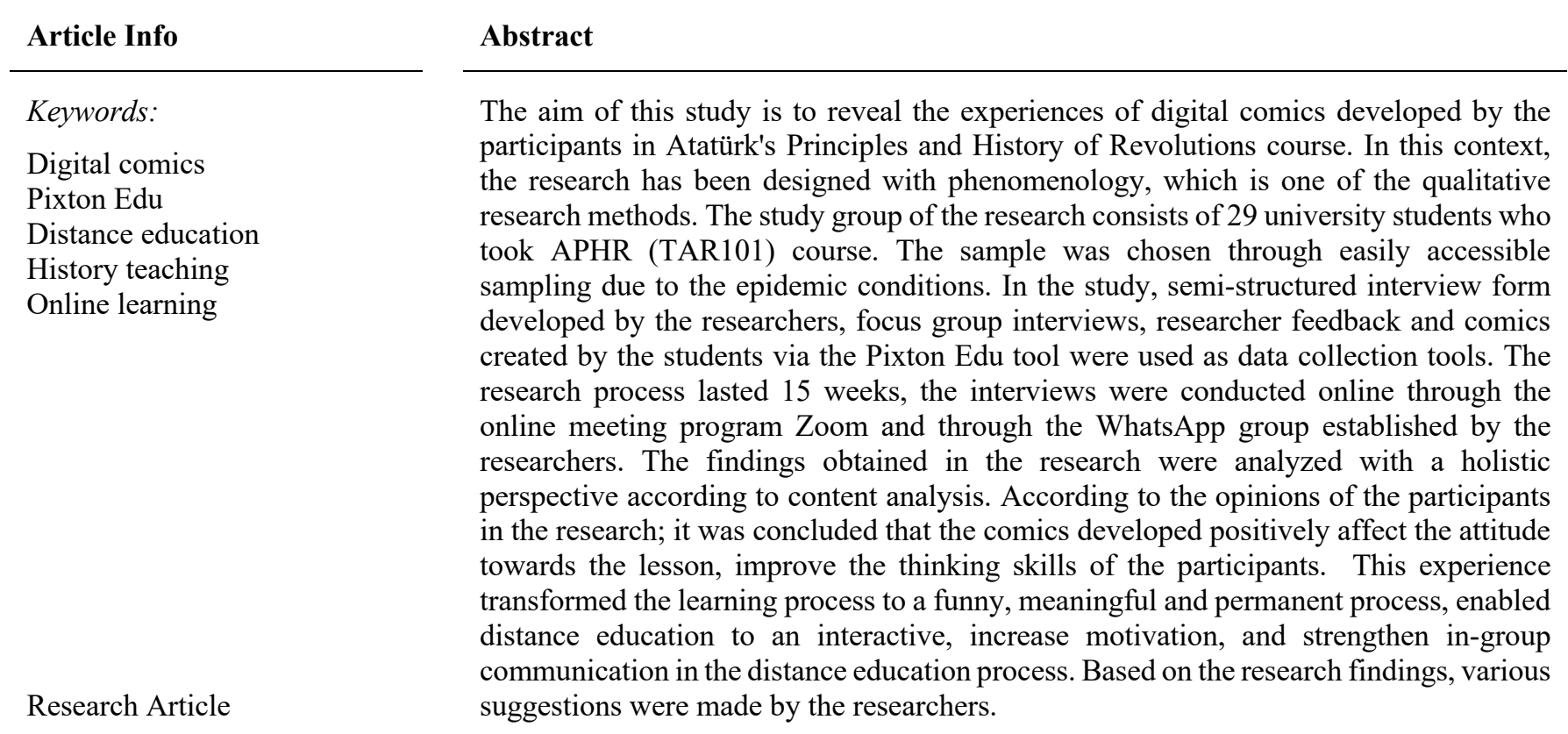

\section{Introduction}

The coronavirus pandemic affected the current academic year 2020-2021 worldwide and the emergency remote teaching process happened a necessary process in all higher education institutions. The pandemic also negatively affected the learning process (Bozkurt \& Shama, 2020). In such an environment, educators have started to think about what can be done both to motivate students and to achieve the gains of the course. In this context, with the development of technology, the idea of using various applications that can compel students' interest in the distance education process, facilitate the transfer of information about the lessons, and trigger the creativity of students has come into play (Ünsal, 2004). Educators with an interest in these subjects and able to adapt new technologies to their courses have made it their goal to make learning environments more active for students and forced to start an "isolated" university life away from friends and the school environment. Unlike face-to-face education, the use of materials has also changed in the distance education process (Bostan Sarığlan, Altaş \&Şen,2021, Sari \& Nayır, 2020). It will be beneficial to use digital learning tools that will motivate students, facilitate their learning, and strengthen their communication during difficult learning processes. There are so many versions of these tools. Digital

\footnotetext{
* Corresponding author. Application and Research Center of the Principles of Atatürk and Turkish Revolution History, Turkey. e-mail address:nihanerol@gazi.edu.tr
} 
storytelling tools, tools for educational games, and tools for creating educational digital comics. In this study we used digital comics via Pixton Edu.

\section{Literature}

Comics, which occur when text and paintings merge and form a whole, are educational material (Ünal \& Demirkaya, 2019) used from the past to improve the efficiency of the teaching process. Researchers have suggested that comics are an effective teaching material in increasing students' motivations for the course and individual participation in the course (Beard \& Rhodes, 2002; Brocka, 1979; Haugaard,1973; Topkaya, 2014, Topkaya \& Şimşek, 2015, Ilhan, 2016; Ilhan \& Oruç, 2019; Comics with positive effects both cognitively and sensitively in the student (Topkaya \& Lightning, 2015) need to have certain criteria before they can use them as educational materials. These criteria are; script and subject matter - character integrity, suitability for student readiness level and the attainment intended to be taught can be ranked as forming the comic's main idea (Topkaya, 2014). Comics used as a teaching material have also entered into transformation and started to be produced and used in digital environment. The online platform called "Pixton Edu" is also a teaching material created to produce and use educational comics.

Pixton Edu is a tool that can make designs for various course contents through comics and graphic arts. This learning tool, which offers paid version and free trial options, has been presented to users with many content packages from mathematics to history, from current topics to art. With this tool, teachers can create a virtual classroom with their students and assign them with assignments. In addition, thanks to this tool, teachers can create visuals that they can use in their lessons and prepare materials that enable students to participate. In addition to these, this tool stimulates students' imagination and supports their creativity. Students can prepare scenarios related to their learning styles and preferences according to the content of the subjects, and they can make their own products. Pixton Edu is an easy-to-use learning tool that encourages collaborative work and creativity. Pixton Edu also has features such as providing feedback, sharing content online and downloading comics (Cabrera, Castillo, González, Quiñónez \& Ochoa, 2013; Lee, 2013). Pixton is also known as a powerful visual storytelling tool (Azman, F. N., Zaibon, S. B., \& Shiratuddin, N., 2015).

It was thought that alternative teaching methods and digital learning tools could attract the attention of students and increase their motivation towards the lesson during the difficult epidemic process where university students try to continue their lessons at home, away from their friends and school environment. When the relevant literature was examined, it was seen that educational comics were mostly created by researchers and presented to students as teaching materials. Zimmerman (2008) suggested that leaving the speech bubbles in the comics blank and filling these balloons by students can improve many skills such as creative thinking skills. In this context, the Pixton Edu license, which is paid by the researchers, was purchased and made available to students. In this study it is aimed to learn the experiences of the students about the tool they use during the lesson and the effect of the experience on their learning processes.

\section{What are the participants' views about using Pixton Edu on history learning? Methodology}

\subsection{Research Model/Design}

The research was designed with phenomenology, which is one of the qualitative research methods (Y1ldırım $\&$ Simsek, 2013). The phenomenological pattern is a qualitative research design used to reveal phenomena that we are aware of but do not know in detail. Perceptions, orientations, situations and concepts in lived experiences constitute the phenomenon to be investigated. Although these phenomena are encountered in daily life, it does not mean exactly how we make sense of the facts. In this context, phenomenology research is used to reach the essence of the phenomena that occur. The research area of phenomenology is social actions and behaviors experienced in daily life. The essence of the experienced phenomenon includes the main meanings (Creswell, 2015). In research generated by the pattern of facts, data should be collected by individuals or groups who have experienced the phenomenon one-on-one and can accurately reveal the 
main meaning of the phenomenon. In this context, a working group in a factual study should have experienced the phenomenon being investigated (Y1ldirım \& Simsek, 2013). The study is based on the 14week course experience of participants and researchers and online meetings scheduled outside of class. Participants were trained by the researchers to use the Pixton tool within the scope of the study. The work carried out was checked in the meetings held and the progress of the work was ensured. In addition, the researchers had the opportunity to observe the experiences by staying in constant interaction with the participants.

\subsection{Data Collecting Tools}

In the phenomenological design, phenomenological interviewing is the primary data collection method to obtain the basic structure or truth underlying the meaning of the experience (Merriam, 2013). Phenomenology includes data obtained from one or more interviews with participants (Creswell, 2015). Qualitative interviews usually involve an open-ended process involving a few questions to elicit the views and opinions of the participants (Creswell, 2015). In addition to interviews, the diary or notes of the observation and study group can also be used as a data collection tool in phenomenological research. In this context, the semi-structured interview form developed by the researchers as the primary data collection tool for the use of Pixton Edu was used in the study. In addition to the interview form, the researchers conducted focus group discussions over the Zoom 3 times, between 90-45 minutes. Focus group interviews were recorded as video, with the permission of the participants, in order to prevent data loss. In addition, pixton date assignments, researcher comments and WhatsApp group messages are among the data collection tools of the research to ensure data diversification.

\subsection{Sampling and Study Group}

The study group was determined by convenience sampling, which is one of the purposeful samples. An easily accessible sample is preferred to bring speed and practicality to the study (Yıldırım \& Şimşek, 2006). In addition, due to the epidemic process, this sample was preferred, considering the fact that the participants are among the student groups that researchers can easily reach. In this context, 29 students who enrolled the mandatory course of Atatürk's Principles and History of Revolution (TAR101) from a state university in Ankara at their fresman year -took part in the study group. 12 of the participants are female and 22 of them are male. Coding was made to keep the names of the participants anonymous. Students are required to have computers in order to use the Pixton tool for the study. Due to this reason, all classes were announced and volunteering was taken into account in selecting participants among the students who can provide these criteria.

\subsection{Data Analysis}

The data obtained in the research were analyzed by content analysis. The purpose of content analysis is to reach concepts and relationships that can explain the data obtained. In this context, through content analysis, it is tried to define the data and reveal the facts that may be hidden in the data. The basic process in content analysis is to gather similar data within the framework of certain concepts and themes, and to interpret and describe them in a way that the reader can understand (Yıldırım \& Şimşek 2006).

\subsection{Validity and Reliability}

The pilot study of the semi-structured interview form for the use of Pixton Edu developed by the researchers was carried out with four students and one question was revised. After the pilot study was completed, the interview form was presented to the opinions of three field experts, and a final form was given by removing one question and adding two questions. Since the focus group interviews are aimed at the process, they were created to determine the problems that may arise by the researchers. Researcher comments on the developed comics were examined by both researchers and the reliability of the comments was increased. Whatsapp group messages are both saved and made available to each participant. During the research and in the creation of the data, the participants were informed that all personal information would be stored and 
the participants were selected on a voluntary basis. Participants' names were coded as K1, K2, K3, K4.... In the analysis of the data, the frequencies differ from each other because some of the participants gave multiple answers falling into more than one category $(\mathrm{n}=29)$.

\subsection{Research Procedures}

The study took place in the fall semester of 2020-2021 over a 15-week course period. For this study, the participants were asked to design educational comics within the scope of Ataturk's Principles and History of Revolution course using Pixton Edu. For this purpose, the working process has been completed with the following order.

\section{- The process of interacting with the participants (15.10.2020-17.11.2020)}

Due to the corona virus epidemic period, it was not possible to meet with the participants face-to-face, and the participants were worked with through distance education tools throughout the application. At the beginning of the semester, students were contacted by a bulk message method through a program called LMS, which is currently used at the university, and information was given about the activities to be held during the semester and the course process. LMS is a versatile program that provides both live lessons and tools for students to share files. This program continued to be used throughout the distance education process.

In the live lessons held in the first week of the practice, the researcher conducting the lesson introduced the subjects using active teaching methods, introducing digital tools that can be used in the history lesson, and using these tools during the lesson. General presentations were made in the first and second weeks, and in the third week, participants were informed about their visa and final assignments. Using the Google forms and LMS system, students were presented with visa and final assignment options, and they were asked to choose among these options.

\section{- Establishment of Pixton Group (17.11.2020-23.11.2020)}

Whatsapp group link was sent to the students who chose pixton homework option from Google forms and the group was established. In this group, the students were introduced to the warm-up activity. The planning of the first meeting was also done jointly with the students in this group. The Whatsapp group was used almost every day throughout the entire application process, creating a dynamic structure in both the instructors 'announcements and the students' information exchange. During the past week, the unlimited version of the Pixton Edu tool was made available by the researchers, and the registration process of the virtual classroom was carried out by obtaining the e-mail addresses of the students. Pixton Edu allows users to create avatars. Students who became members of the virtual class started to create their own avatars and examine the tool. 


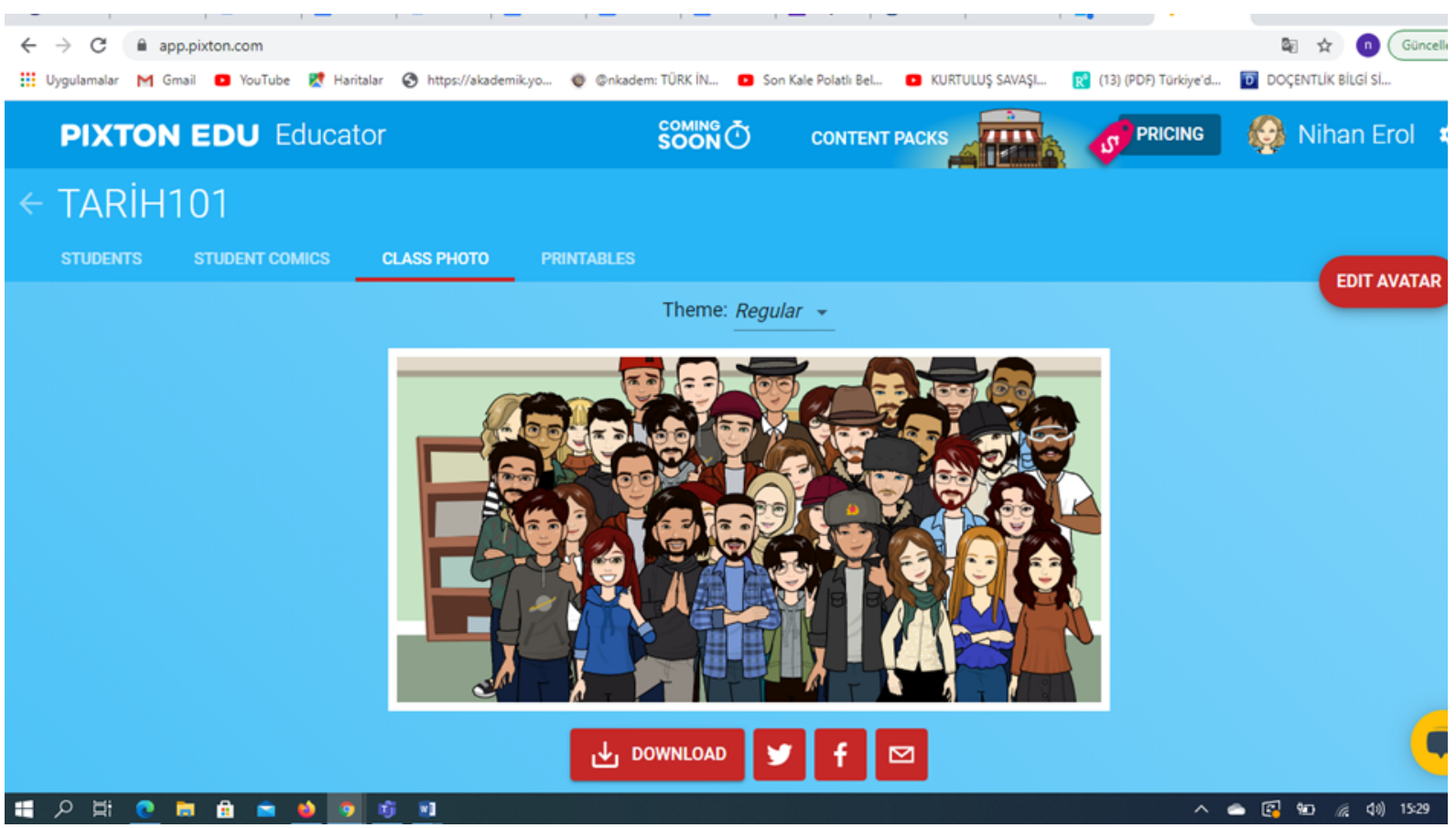

Fig. 1. Pixton Classroom Photo

\section{- Zoom Meeting- First Focus Group Meeting (23.11.2020)}

The purpose of this meeting is to introduce the pixton edu tool to the students, to give detailed information about the assignment and to receive pre-interview records. Within the permission of the students, the zoom meetings were recorded. This meeting was held in two separate sessions, in the first session, information was given about the tool, and then the questions of the students about the tool were answered. Detailed information on the evaluation criteria was also given in this meeting. After this meeting, the students started to write the script.

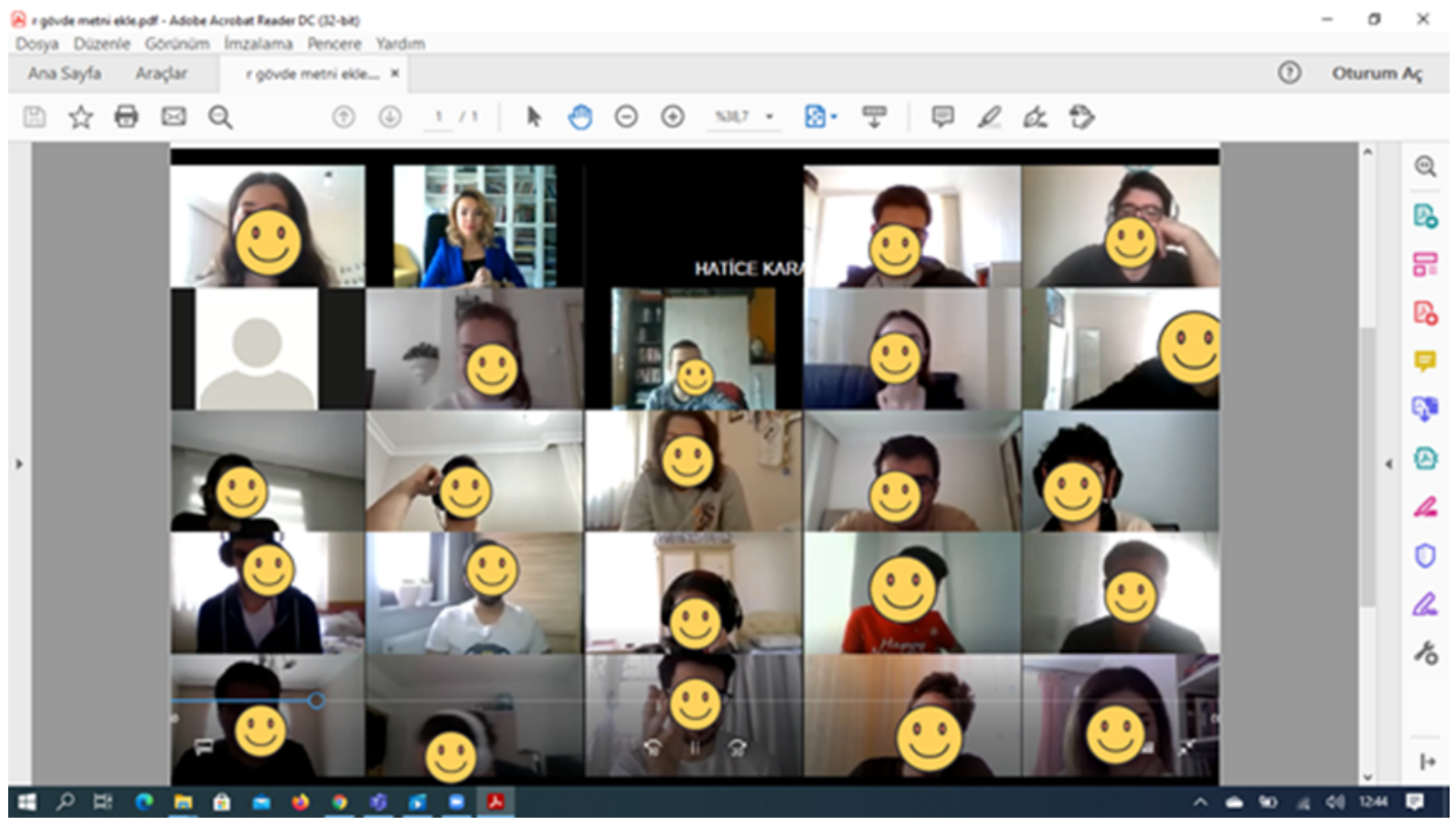

Fig. 2. Zoom Meeting Photo 
- Preparation of the First Reports and Feedback from the Trainers via Pixton (23.11.202013.12.2020)

In the last 3 weeks, students uploaded the reports they prepared according to the determined criteria to the system. At this stage, the demands from students are as follows;

1- The main idea of the script is related to the historical subject they have chosen,

2- Using at least 3 different historical sources to create the scenario,

3- The compatibility of the characters with the script,

4- The progress of the scenario as a plot.

Students started to create their comics within the given time. The comics that the students started to create were followed daily by the researchers and suggestions were given for the parts that need to be corrected. The process was followed in this way until the comics were completed. During the preparation of the comics, the Whatsapp group was also used very actively, and the students found solutions to their problems by asking questions to both their friends and researchers when they had difficulties. In the screenshots below, examples of the feedback given to students are presented.

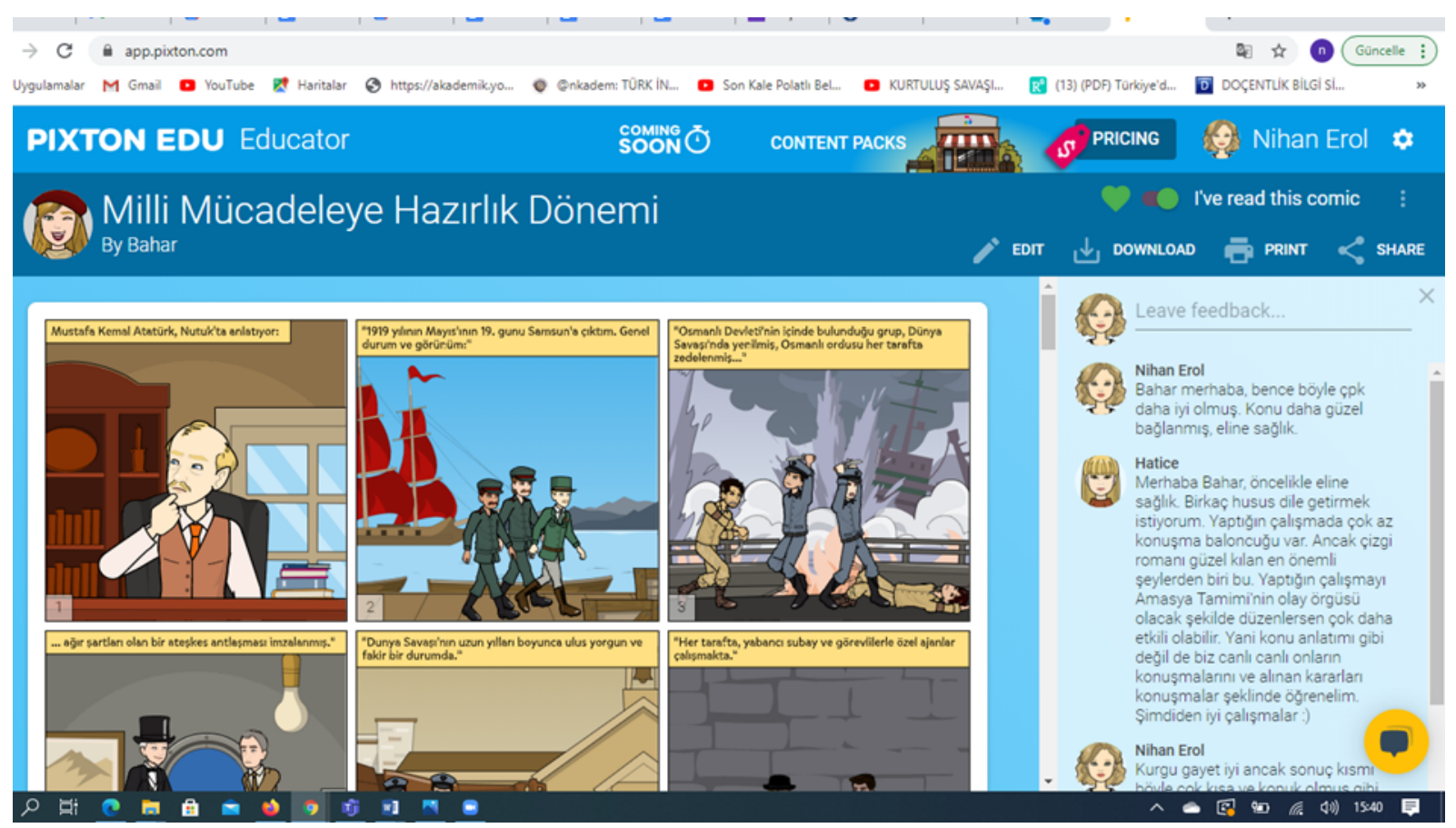

Fig. 3. Example of feedback given to students 


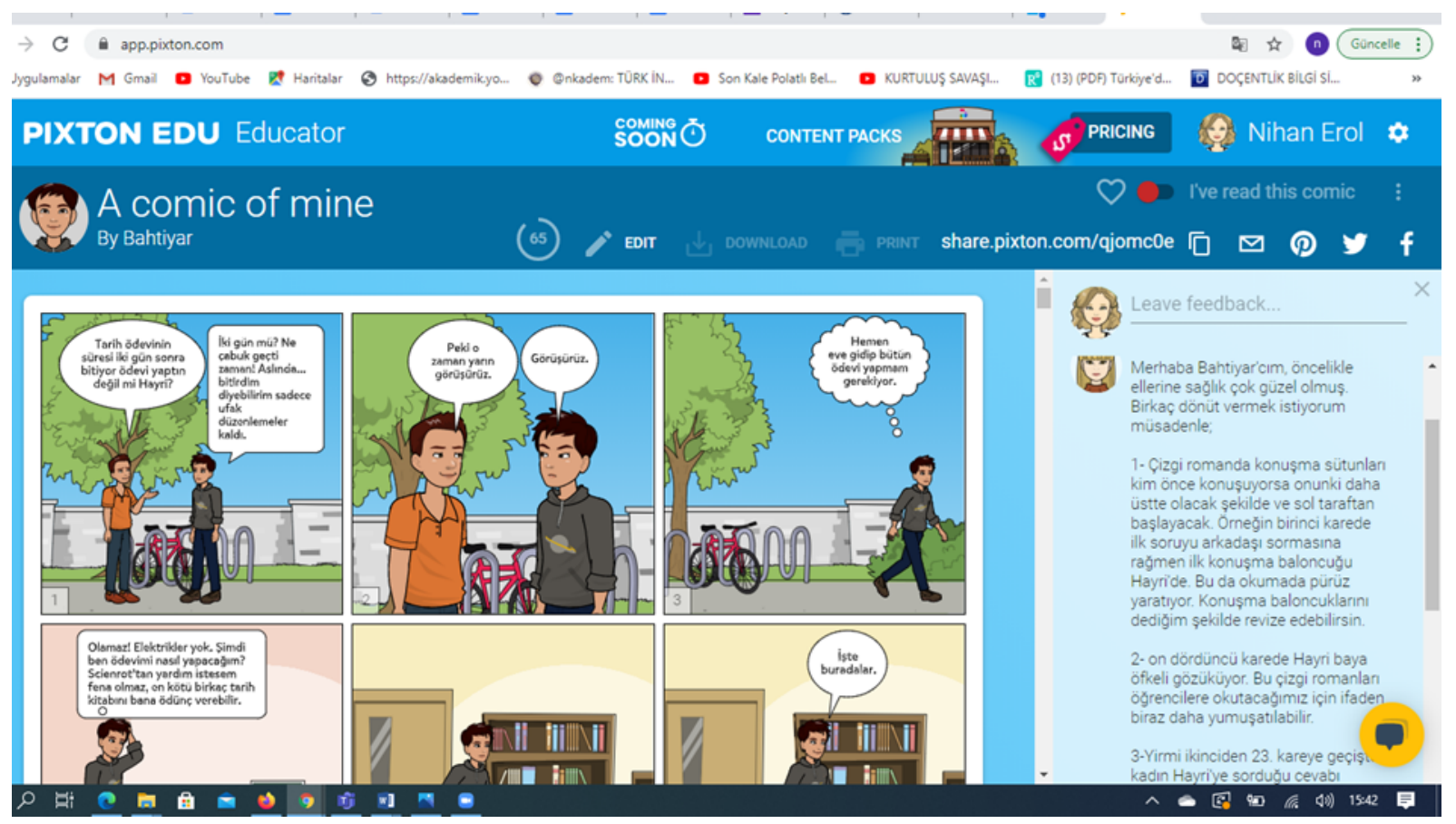

Fig. 4. Example of feedback given to students

- Making the final arrangements, zoom meeting for the corrections to be made, making the comics ready for upload (13.12.2020-15.01.2021)

In the last weeks of the study, the students made the necessary corrections in their comics according to the feedback given, and at the zoom meeting, the researchers and the participants presented solutions to the problems experienced in cooperation. As can be seen in the screenshots, the participants solved the problems they faced during the preparation of the comics, both with the guidance of the researchers and by exchanging information with their peers.

- The process of uploading the prepared comics to the LMS and evaluating by the researchers according to the specified criteria (15.01.2021-27.01.2021)

As stated at the beginning of the study, this study was given to the students in the form of visa and final assessment homework. The students uploaded their Pixton homework to the LMS system and were evaluated according to the criteria determined within three weeks. During this period, the opinion form prepared by the researchers was sent to the students.

- Last zoom meeting - focus group (27.01.2021)

The last meeting is planned as a focus group meeting. In this meeting, where 10 participants from a group of 29 participants attended, open-ended questions were asked to the participants, and detailed data were obtained for the study. While the implementation part of the research, which started in October, was ended with the focus meeting, it continued to interact with the participants through the WhatsApp group and LMS system.

\subsection{Findings and Discussions}

In the research, the data obtained from focus group interviews, semi-structured interview form and researcher observation and feedback were analyzed with a holistic perspective and presented below.

The findings obtained regarding the question asked to the participants about their experiences about the Pixton Edu are presented in Table 1. 


\section{Table 1.}

Participants' views on Pixton Edu Tool

\begin{tabular}{|c|c|c|c|c|}
\hline Theme & Category & Code & $\mathbf{f}$ & Participant \\
\hline \multirow{11}{*}{$\begin{array}{l}\text { Program } \\
\text { Operation }\end{array}$} & \multirow{8}{*}{$\begin{array}{l}\text { Advantage } \\
\text { Dimension }\end{array}$} & Easy interface & 11 & $\begin{array}{c}\mathrm{K} 7, \mathrm{~K} 22, \mathrm{~K} 12, \\
\mathrm{~K} 18, \mathrm{~K} 22, \mathrm{~K} 23, \\
\mathrm{~K} 24, \mathrm{~K} 28, \mathrm{~K} 27, \\
\mathrm{~K} 26, \mathrm{~K} 25\end{array}$ \\
\hline & & Template character & 1 & K16 \\
\hline & & $\begin{array}{c}\text { Creating an } \\
\text { interactive effect }\end{array}$ & 2 & $\mathrm{~K} 3, \mathrm{~K} 5$ \\
\hline & & Facilitating learning & 2 & K4, K6 \\
\hline & & Versatile application & 1 & K7 \\
\hline & & A useful tool & 1 & K1 \\
\hline & & Fun tool & 5 & $\begin{array}{l}\mathrm{K} 8, \mathrm{~K} 10, \mathrm{~K} 15, \\
\mathrm{~K} 18, \mathrm{~K} 23\end{array}$ \\
\hline & & $\begin{array}{l}\text { A different } \\
\text { experience }\end{array}$ & 1 & K17 \\
\hline & \multirow{3}{*}{$\begin{array}{l}\text { Disadvantage } \\
\text { Dimension }\end{array}$} & Restricted Content & 6 & $\begin{array}{c}\mathrm{K} 2, \mathrm{~K} 4, \mathrm{~K} 7, \mathrm{~K} 9, \\
\mathrm{~K} 10, \mathrm{~K} 6\end{array}$ \\
\hline & & $\begin{array}{l}\text { Content limitation } \\
\text { due to educational } \\
\text { content }\end{array}$ & 7 & $\begin{array}{c}\mathrm{K} 28, \mathrm{~K} 19, \mathrm{~K} 21, \\
\mathrm{~K} 23, \mathrm{~K} 29, \mathrm{~K} 27, \\
\mathrm{~K} 26\end{array}$ \\
\hline & & $\begin{array}{c}\text { Technical } \\
\text { deficiencies }\end{array}$ & 3 & $\mathrm{~K} 12, \mathrm{~K} 28, \mathrm{~K} 25$, \\
\hline
\end{tabular}

When Table 1 is examined, it is seen that the views of the participants about the program are gathered under the "advantage" and "disadvantage" categories. Most of the participants are of the opinion that the interface of the program is user-friendly. Some of the opinions of the participants in the "advantage" category are presented below.

K1... The interface was very simple and versatile, so it did not have much difficulty. I think it is a powerful form of expression because it visualizes the person's thinking. The use of the program offers a comfortable working process ...

K18: ... It is really nice in terms of application interface and usage and easy to use.

K22: ... I didn't have any difficulties. It made the lesson much more interactive and increased my enthusiasm …

Although most of the participants found the tool easy and fun, some participants stated that they had some difficulties while using the program. Some of the opinions of the participants regarding the "disadvantage" category are presented below.

K28: ... We did not have to deal with it one by one since it was made using pre-designed templates. But it took me quite a while to choose the characters and background images that I think could describe the event accurately and suitable for each scene. At times, I had difficulty finding suitable places and clothes for 
history. Since the Pixton site is a completely media-based site, it was a very nice experience, even though I have occasionally experienced freezes from the site ...

K21:... Difficulty of the tool; The background was limited and we could not create a character with the features we wanted completely while designing the characters. If we think about it for the history homework, I think it was a problem for us to reflect the exact period in the clothing (such as fez) and facial types such as beard, especially mustache, but despite this difficulty, it was a very entertaining homework. The presence of many faces, gestures and movements occasionally made us laugh and entertain us while doing our homework.

K8:... The application was designed to be used by everyone. I had no difficulty creating the boards. But I wish I could download the comic in one go. In addition, the absence of some objects (such as a weapon) was a bit of a challenge ...

When the opinions of the participants were analyzed, it was seen that they had some difficulties due to the features of the Pixton tool. While becoming a Pixton member such as parent membership, educator membership, student membership and business membership options are offered. Since an educational content will be designed, the researchers became members with an educator account. The tool also brought some restrictions for being a member of this account. Objects related to harmful habits such as weapons and tobacco products are not included in the add-ons. Due to this situation, the participants who wanted to use objects such as weapons in the war scenes stated that they had difficulties. Participants, who thought of creative solutions to find a solution to this limitation, managed to create a war scene without using weapons. An example of this situation is given below.

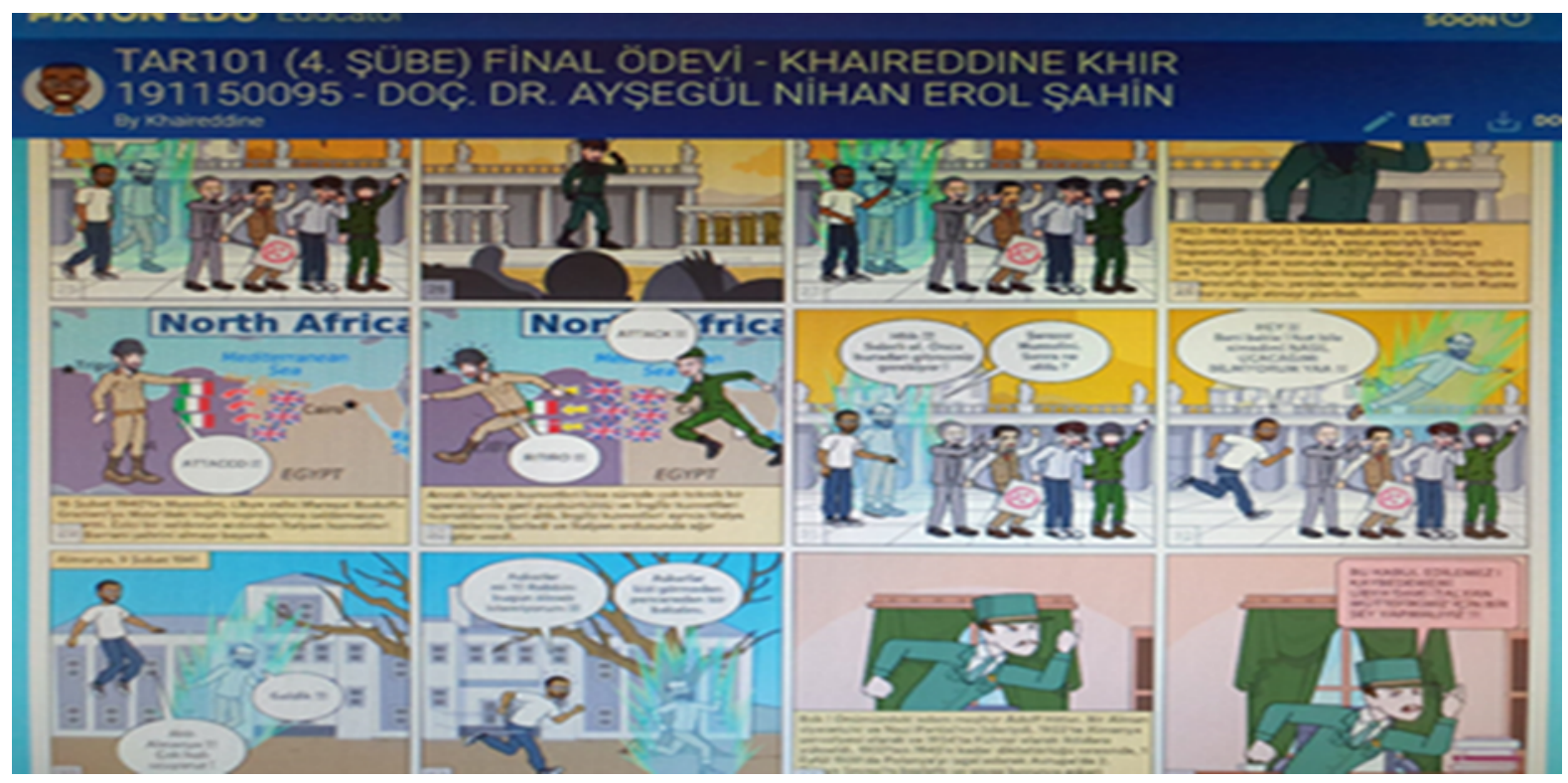

Fig. 5. Example-war scene from participant comics

Participants were asked in what ways the homework they prepared with the Pixton Edu were beneficial for their understanding of the subject they researched, and the findings were presented in Table 2. 


\section{Table 2.}

Participants' views on the effect of Pixton Edu use on learning

\begin{tabular}{|c|c|c|c|c|}
\hline Theme & Category & Code & f & Participant \\
\hline \multirow{14}{*}{$\begin{array}{c}\text { Relationship } \\
\text { Between Tool - } \\
\text { Course }\end{array}$} & \multirow{7}{*}{ Skill Dimension } & Empathize & 1 & K4 \\
\hline & & $\begin{array}{c}\text { Historical } \\
\text { understanding }\end{array}$ & 2 & $\mathrm{~K} 1, \mathrm{~K} 25$ \\
\hline & & Cognitive Skill & 1 & $\mathrm{~K} 20$ \\
\hline & & $\begin{array}{c}\text { Historical } \\
\text { analysis skills }\end{array}$ & 2 & $\mathrm{~K} 7, \mathrm{~K} 25$ \\
\hline & & $\begin{array}{l}\text { Historical } \\
\text { Empathy }\end{array}$ & 2 & $\mathrm{~K} 25, \mathrm{~K} 15$ \\
\hline & & Critical Thinking & 1 & $\mathrm{~K} 25$ \\
\hline & & $\begin{array}{l}\text { Change - } \\
\text { Continuity }\end{array}$ & 1 & K11 \\
\hline & \multirow{5}{*}{$\begin{array}{l}\text { Meaningful } \\
\text { Learning } \\
\text { Dimension }\end{array}$} & $\begin{array}{l}\text { Facilitating } \\
\text { learning by } \\
\text { making the } \\
\text { subject cartoon }\end{array}$ & 3 & $\mathrm{~K} 3, \mathrm{~K} 2, \mathrm{~K} 6$ \\
\hline & & $\begin{array}{l}\text { The combination } \\
\text { of the subject } \\
\text { being researched } \\
\text { and the } \\
\text { imagination }\end{array}$ & 2 & K9, K5 \\
\hline & & $\begin{array}{l}\text { Permanent } \\
\text { understanding by } \\
\text { strengthening } \\
\text { historical content } \\
\text { with visuals }\end{array}$ & 4 & $\begin{array}{c}\mathrm{K} 23, \mathrm{~K} 28, \mathrm{~K} 24, \\
\mathrm{~K} 22\end{array}$ \\
\hline & & $\begin{array}{l}\text { Making the } \\
\text { lesson fun and } \\
\text { easy to } \\
\text { understand }\end{array}$ & 2 & $\mathrm{~K} 3, \mathrm{~K} 17$ \\
\hline & & $\begin{array}{l}\text { Integrating } \\
\text { history lesson } \\
\text { with life }\end{array}$ & 1 & K25 \\
\hline & \multirow[t]{2}{*}{ Material } & $\begin{array}{l}\text { Using different } \\
\text { tools to write } \\
\text { interesting } \\
\text { scenarios }\end{array}$ & 1 & K29 \\
\hline & & $\begin{array}{c}\text { Learning to use a } \\
\text { new and } \\
\text { enjoyable } \\
\text { application }\end{array}$ & 1 & K27 \\
\hline
\end{tabular}




\begin{tabular}{|c|c|c|c|}
\hline \multirow{4}{*}{$\begin{array}{c}\text { In-Depth } \\
\text { Examination } \\
\text { Dimension }\end{array}$} & $\begin{array}{l}\text { Research from } \\
\text { different sources }\end{array}$ & 6 & $\begin{array}{c}\mathrm{K} 8, \mathrm{~K} 9, \mathrm{~K} 3, \\
\mathrm{~K} 16, \mathrm{~K} 20, \mathrm{~K} 18\end{array}$ \\
\hline & $\begin{array}{l}\text { The subject being } \\
\text { researched } \\
\text { becomes catchy }\end{array}$ & 4 & $\begin{array}{c}\mathrm{K} 3, \mathrm{~K} 9, \mathrm{~K} 2, \\
\mathrm{~K} 28\end{array}$ \\
\hline & $\begin{array}{l}\text { Detailed research } \\
\text { on the topic }\end{array}$ & 9 & $\begin{array}{r}\mathrm{K} 8, \mathrm{~K} 10, \mathrm{~K} 12 \\
\mathrm{~K} 26, \mathrm{~K} 13, \mathrm{~K} 27, \\
\mathrm{~K} 23, \mathrm{~K} 22, \mathrm{~K} 21\end{array}$ \\
\hline & $\begin{array}{l}\text { The need to } \\
\text { master the subject } \\
\text { in detail for short } \\
\text { and concise } \\
\text { expression }\end{array}$ & 1 & K9 \\
\hline
\end{tabular}

When Table 2 is examined, it is seen that the homework done with Pixton Edu is beneficial in many different ways in understanding the researched subject. It was determined that the opinions of the participants were gathered under the categories of "skill", "meaningful learning", "material" and "in-depth examination". Some of the opinions of the participants regarding the "skill" category are presented below.

K4. ... The tool helped me to understand the subject I researched in depth, because we looked through the eyes of the characters, so we were able to look at the subject from other perspectives.

K25. ... It was definitely beneficial. Here, my professor's contribution is more than anything else. The biggest contribution to the history lesson, after my teacher, who made me understand better that it is life itself rather than a lesson, is pixton. I witnessed the chance to go back to that period and empathize more while making each frame. I questioned it more, I found a place in the cartoon I made for myself ...

K1. ... It was very useful because I combined the information I researched with my imagination and turned it into a memorable work.

K7. ... We had to write every dialogue on the subject as realistically as possible. That's why it was necessary to look at the event from every angle ...

P9:... Yes, since we looked through the eyes of the characters, we were able to look at the subject from other perspectives.

K8. ... Yes, because when I was doing pixton, I did the subjects with a feeling as if I have experienced them...

K20. ... I had to do research on the subject in order to create the story about the subject. In addition, I believe that not giving the information in a raw way throughout the novel and keeping the story in harmony makes brain practice and has a positive effect on intelligence.

It can be said that the participants used historical understanding, analysis and empathy skills in the process of researching the subject they chose, scripting and creating their comics. This situation is also noticed in the comics prepared by the participants. In addition to the opinions of the participants, the comics created by the participants were also examined and the comments of the researchers are given below.

R1:... When the participant comics are examined, it is seen that 1,25, 8 and 9 create scenarios on "National Struggle/War of Independence". Participants have included historical personalities within this subject. For example, while preparing the K25 comic in which Kazlm Karabekir is in the script, he did research from many sources, examined dozens of photographs, and shaped his work to be both 
realistic and fit the flow of the script. It can be said that in these comics prepared with great effort, students actually use many skills without realizing it. This situation can be understood in more detail in the opinions of the focus groups. Focus Group K8: ... "My teacher, what did the people who shaped history feel when the incident was taking place, when those historical words were uttered, how was the expression on their faces, what did they think? ... I found myself thinking about these when I put my script into a comic book. It is as if I have experienced the subject that I had read and passed through before ".

Participant views and our observations during the process can be demonstrated that students use a large number of skills in the process of preparing scenarios and creating comics.

Some of the opinions of the participants on the "meaningful learning" and "deep exploration" categories are presented below.

K23:... Of course it helped. I researched the subject in more detail in order to make detailed panel

K3:... It happened, because I researched the subject thoroughly to provide accurate information, and it was memorable because I had fun while doing it.

K16:... In order to make a comic book with Pixton, it is necessary to be familiar with the subject first. For this, you need to read from different sources. The information you have gained from these readings is collected in a pool and you constantly dive into this pool of knowledge while setting up, designing and drawing the script in your mind, and this ensures that you have a good understanding of the subject ...

K9:... okay. It was necessary to have every aspect of the event in order to explain it succinctly ...

K12:... Yes, it happened. Because in order to prepare this assignment, a really deep, clear and complete knowledge is needed on the subject. Whenever I tried to write the script and prepare the characters, I realized that my research was not enough and I needed to have a little more knowledge....

When the participants' opinions are analyzed, it is seen that they give answers in the dimension of meaningful learning and in-depth examination. Participants stated that while writing their scenarios on the topics they chose, they investigated the subject in detail and therefore learned in depth, and stated that their learning was also permanent. In addition to these data, the researcher's opinion is as follows;

R1:... The first stage of this assignment prepared by the participants was the scenario creation process. Participants also wrote down what sources they benefited from in the reports they presented to us in this process. We observed that the participants made more detailed research on the subject in the second stage, in the process of creating a comic book. The answer given by one of the participants in the focus group interview can be given as an example to this situation;

Focus Group K25: I chose the "Amasya Circular" subject in my comic book, now I wish I had taken the whole process. Because the Amasya Circular remained in my mind with all the details. I cannot say the same for other subjects...

Participant 26's answer explains the situation of in-depth examination of the subject in detail;

K26:... It definitely happened. To tell a topic within a plot from start to finish, you need to have a full grasp on that topic, otherwise there may be disconnections and meaningless connections between scenes, which does not give any correct results for the reader. Therefore, I prepared my homework by researching the whole subject in depth and supporting it with various readings and arguments, and this helped me learn the subject in depth ...

Some of the opinions of the participants in the "material" category are presented below. 
K29:... Yes, there were great benefits. I had to use different tools and pay close attention to small details to create a suitable and interesting script. Finally, I both understood the subject well and learned to use a new enjoyable application...

Participants were asked for their views on the use of Pixton Edu in the distance education process due to the pandemic, and the findings are presented in Table 3.

Table 3.

Participants' views on the effect of pixton edu use on distance education

\begin{tabular}{|c|c|c|c|c|}
\hline Theme & Category & Code & f & Participant \\
\hline \multirow{18}{*}{$\begin{array}{l}\text { The Relationship } \\
\text { Between Tool- } \\
\text { Distance Education } \\
\text { Process }\end{array}$} & $\begin{array}{l}\text { Evaluation of } \\
\text { Learning } \\
\text { Dimension }\end{array}$ & $\begin{array}{l}\text { Reliability of } \\
\text { the assessment } \\
\text { method }\end{array}$ & 1 & K20 \\
\hline & \multirow[b]{5}{*}{$\begin{array}{l}\text { Learning } \\
\text { Dimension }\end{array}$} & $\begin{array}{c}\text { Making } \\
\text { distance } \\
\text { education fun }\end{array}$ & 16 & $\begin{array}{c}\mathrm{K} 2, \mathrm{~K} 3, \mathrm{~K} 8, \mathrm{~K} 9, \\
\mathrm{~K} 10, \mathrm{~K} 11, \mathrm{~K} 17, \\
\mathrm{~K} 12, \mathrm{~K} 18, \mathrm{~K} 19, \\
\mathrm{~K} 16, \mathrm{~K} 13, \mathrm{~K} 15, \\
\mathrm{~K} 22, \mathrm{~K} 4, \mathrm{~K} 23\end{array}$ \\
\hline & & $\begin{array}{c}\text { Providing an } \\
\text { active learning } \\
\text { environment }\end{array}$ & 3 & $\mathrm{~K} 12, \mathrm{~K} 13, \mathrm{~K} 28$ \\
\hline & & $\begin{array}{l}\text { Making sense } \\
\text { of the subject }\end{array}$ & 4 & $\mathrm{~K} 4, \mathrm{~K} 11, \mathrm{~K} 21, \mathrm{~K} 10$ \\
\hline & & $\begin{array}{l}\text { Facilitating } \\
\text { learning }\end{array}$ & 3 & $\mathrm{~K} 8, \mathrm{~K} 10, \mathrm{~K} 13$ \\
\hline & & $\begin{array}{l}\text { Learning } \\
\text { historical } \\
\text { information } \\
\text { and research } \\
\text { methods } \\
\end{array}$ & 2 & K29, K21 \\
\hline & Interaction & Socializing & 2 & $\mathrm{~K} 7, \mathrm{~K} 25$ \\
\hline & Dimension & Contact & 1 & $\mathrm{~K} 25$ \\
\hline & \multirow{2}{*}{$\begin{array}{c}\text { The Dimension of } \\
\text { Attitude Towards } \\
\text { the Course }\end{array}$} & $\begin{array}{c}\text { Increasing } \\
\text { interest in } \\
\text { history lesson } \\
\end{array}$ & 3 & $\mathrm{~K} 13, \mathrm{~K} 15, \mathrm{~K} 14$ \\
\hline & & $\begin{array}{l}\text { Developing a } \\
\text { positive } \\
\text { perspective } \\
\text { towards the } \\
\text { history lesson }\end{array}$ & 2 & K27, K1 \\
\hline & \multirow{2}{*}{$\begin{array}{c}\text { Personal } \\
\text { Development } \\
\text { Dimension }\end{array}$} & $\begin{array}{l}\text { Revealing the } \\
\text { artistic side }\end{array}$ & 1 & K26 \\
\hline & & $\begin{array}{c}\text { Developing } \\
\text { creativity } \\
\text { skills } \\
\end{array}$ & 2 & K20, K26 \\
\hline & \multirow{5}{*}{$\begin{array}{c}\text { Personal } \\
\text { Satisfaction }\end{array}$} & $\begin{array}{l}\text { Enjoyable } \\
\text { time }\end{array}$ & 1 & K24 \\
\hline & & $\begin{array}{c}\text { Spending } \\
\text { quality time }\end{array}$ & 1 & K11 \\
\hline & & $\begin{array}{l}\text { Having a } \\
\text { different } \\
\text { experience }\end{array}$ & 2 & K1, K5 \\
\hline & & $\begin{array}{c}\text { Using as a } \\
\text { means of self- } \\
\text { expression }\end{array}$ & 1 & K1 \\
\hline & & Stress reliever & 2 & $\mathrm{~K} 8, \mathrm{~K} 23$ \\
\hline & $\begin{array}{l}\text { Material } \\
\text { Dimension }\end{array}$ & $\begin{array}{l}\text { Learning a } \\
\text { new } \\
\text { application }\end{array}$ & 5 & $\begin{array}{c}\text { K5, K6, K20, K15, } \\
\text { K16 }\end{array}$ \\
\hline
\end{tabular}


When Table 3 is examined, it is revealed that using the Pixton Edu tool in the distance education process provides benefits in many different ways. It was determined that the participants' views were collected under the categories of "evaluation of learning", "learning", "interaction", "attitude towards the lesson", "personal development", "personal satisfaction" and "material". Some of the opinions of the participants on the category of "learning" are presented below.

K3:... Honestly, it contributed a lot. Among many boring lessons, our history lessons passed with fun...

K10:... Pixton contributed to our understanding of the subject by adding a fun and different experience during these periods when we had difficulty understanding the lessons.

K11:... It was both educational and away from the stress of other lessons. It was fun dealing with Pixton ...

K12:... I think that there is no successful learning during the lesson in the distance education process, certainly it is valid for every lesson. For this reason, we had more to do in this process to complete our own learning, and pixton made it fun. Therefore, I did my homework with interest and completed it ...

P17:... This application enlivened my education in this semester while I was teaching in a classical and monotonous way in the normal lessons in distance education.

K26:... During this period, obviously, normal homework and exams started to become very boring. That's why I chose pixton. This situation was a struggle against something I did not know, and I learned new things because it was a task outside of my comfort zone.

As a result of the epidemic that affected the whole world in the year of the application, lessons were given by distance education. In the statements of most of the participants, it is observed that this process becomes boring for the students. Participants are united in the opinion that the Pixton benefits them in distance education, as it makes the monotonous distance education process more enjoyable and interesting. Apart from making distance education more enjoyable, other views are as follows;

K28:... how nice it is to try to make us active in our classes.

K29:... For me, this app has given me the chance to expand my knowledge on topics and learn how to search for historical details...

Some of the opinions of the participants in the "interaction" category are presented below.

P7:... It contributed to socialization ...

$K 24: . .$. the Zoom meetings held in between were very motivating as they enabled us to socialize and get to know each other even in this period...

P25... Our biggest disadvantage in the distance education process is definitely communication and sociability in education. I think Pixton has helped this situation...

Some of the opinions of the participants in the category of "attitude towards the course" are presented below.

K13:... It increased my enthusiasm for history. Especially in this distance education process, it is a fun and instructive format.

K27:... It positively affected my perspective on history lesson, which I don't like very much.

The researcher's opinion on this subject is presented below.

R2:... Courses that are social sciences such as history always seem a little more boring to the student. Especially thinking that they will memorize overwhelms them. I think educational tools such as digital comics can prevent these thoughts. As we observed, the students both learned a lot of information 
and had a lot of fun during the learning process. Because shaping history in their own hands, with their own imagination was like giving life to life for them...

Some of the opinions of the participants in the "personal development" category are presented below.

K1:... It is an undeniable fact that it is a different experience. Since the producer is the student himself, it is also a means of self-expression. However, I can say that it allowed me to look at the events from a different perspective...

K5:... I met a different application...

K23:... Especially, I learned a new tool and I closed these gaps with a fun application instead of sitting idly at home...

K24:... While it is not possible to rest while doing a given homework under normal conditions, I had the opportunity to take a break from my other work and rest myself while doing this homework. This made me find this assignment very valuable ...

K26:... For myself, I think that the distance education process is more efficient than face-to-face education when properly managed, and this was a very good example. While I could not shoot the scenarios I wrote due to the pandemic, it enabled me to write a script and put it into practice in the form of a comic book. With this nice experience, I can say that I learned the subject I prepared for homework very easily and in depth and while doing this I did it not with the feeling of studying but with the feeling of performing art.

K20:... I can also use this application I learned for my other lessons. For example, comics that will explain the discovery of the unit circle in trigonometry and trigonometric expansions to students in a fun and with a futuristic manner.

Considering that the participants spend most of their time at home and have limited opportunities for personal development, these views are considered to be very important. It seems that the participants stated that they did the homework with pleasure, that they were happy to learn a new tool, that they had the opportunity to rest themselves, and that they even worked like an artist.

The opinion of the researcher on this subject is as follows:

R2:... The pandemic caused the students to suffer in many ways. One of them is to try to teach university courses by distance education, which is difficult even face to face. Faculty members were also in a very difficult situation here. Especially for our faculty members who are in the generation $X$ group, the distance education process has been more difficult in terms of both material and digitalization. For this reason, experiencing such a digital educational tool has been both very effective and very fun for today's students who are in the Generation $Z$ group.

Participant's opinion on the category of "evaluation of learning" is presented below.

K20:... Students cheat in the exams of other courses and take the right of those who do it with their own efforts. At least in this kind of evaluation methods, it is revealed who worked and who did not work and everyone gets their labor. In other words, it contributed to people not being entitled to me

While one of the participants mentioned the problems of the measurement and evaluation process in the distance education process, he emphasized that this study was more sensitive about measurement and evaluation. The researcher's opinion regarding this is as follows;

A1: During the period of the epidemic, I observed that there were problems in measurement and evaluation in some courses in the distance education process, which was implemented somewhat 
quickly. I believe that such situations undermine students' confidence and reduce their motivation. In order to prevent this from happening in my own lesson, we talked to the students at the beginning of the semester in detail, and announced the work to be done and how to score in return for these works. We shared the grades given at the end of the study transparently with the students. I think this system is safe for students.

To find an answer to the question of how the use of Pixton Edu affects motivation, do you think that the use of the tool named Pixton in History lessons increases our motivation for the lesson? The question has been asked.

All 29 participants answered yes to this question. Some examples of the opinions coming from the focus group interviews and the comments of the researchers are as follows;

K3:... The idea of learning an interesting tool unlike other lessons was good. In addition, our whatsup group correspondence, meetings, messages increased my motivation ...

K17:... Frankly, it was enough for me to do a work that is far from monotonous and enjoyable. I could say that I did not get tired while doing, researching, on the contrary, I became happy as I did it and my work was revealed ...

K13:... The things we experienced this period and the fact that we had to stay at home all the time had lost my enthusiasm for many things. Working with such a group increased my enthusiasm. So my interest in the lesson also increased ...

K24: Mrs, one of the things we needed in this period was socializing, what you did, our zoom meetings and correspondence were good for us. Especially the zoom meetings held were very motivating as it enabled us to socialize and get to know each other even in this period ...

The opinion of the researchers, who observed the correspondence of the participants in the whatsapp group and their speeches in the zoom meetings, is as follows:

R1:... We were aware that one of the things that our students, who were deprived of many things due to the epidemic, needed most was motivation. In fact, the main emergence of this study was the idea that "whatever we do, our students will be more interested in history lessons." From the very beginning of the study, we saw that our students had the interest and desire we dreamed of, both in our group correspondence and in our zoom meetings. In fact, we noticed that they often exceeded our expectations. I can say that this situation enabled us to work with more enthusiasm.

\section{Conclusion and Suggestions}

The aim of this study is to reveal the experiences of digital comics created by the participants in Atatürk's Principles and History of Revolutions course. In this context, various conclusions have been reached regarding the 15-week implementation process and the findings obtained from the participants at the end.

Participants stated that the tool had many advantages, as well as a devastating advantage. Especially the easy interface and the presence of ready-made characters in the tool are some of the biggest advantages of the tool. Among its disadvantages, limited content was highlighted. When the literature is examined, such a disadvantage of the tool has not been encountered. One of the reasons for this may be that digital comics are created by researchers, not participants. Another reason may be the opening of the Pixton Edu tool by the researchers because it does not contain weapons and tobacco-containing substances.

In the study, it was concluded that the thinking skills of the participants such as historical empathy, critical thinking skills, change-continuity developed positively. Zimmerman (2008) concluded that filling the speech bubbles by the participants in the comics promotes the development of cognitive skills in the participant. Hobri, Murtikusuma, and Hermawan (2019) concluded that the use of digital comics in 
education positively affects the cognitive, psychomotor and affective aspects. In this context, it can be said that the development of comics by the participants has a positive effect on thinking skills.

In the study, it was concluded that the participants examined the subject they researched by making digital comics in more depth and realized meaningful learning. When the relevant literature is reviewed, Engler, Hoskins, and Payne (2014), Ünal and Demirkaya (2019), İlhan and Oruç (2019), Topkaya (2014), Sones (1944), Hutchinson (1949), Olson (2008), Hosler and Boomer (2011), Efecioğlu (2013) and Richter, Rendings, and Maminirina (2015) concluded that the use of comics in education positively affects academic achievement. In this context, it can be said that digital comics created by the participants positively affect permanent and meaningful learning.

In the study, it was concluded that creating digital comics positively affected the attitude towards history lesson and increased the motivation towards the lesson. Engler, Hoskin, and Payne (2008) Kilickaya and Krajka (2012) noticed that comics help create a positive attitude and increase motivation. On the other hand, Apple and Kikuchi (2007) showed that computer-based material that enables students to have control over content can provide benefits such as being student-centered, motivating, increasing self-confidence and autonomy. Kiriş-Avaroğulları and Mutlu (2019) noticed that pre-service social studies teachers have positive views on preparing and using comic books in the social studies teaching. WCabrira et al. (2013) concluded that the use of digital comics in education not only positively affects students' motivation but also facilitates teaching for teachers. In addition to these, digital comics work collaboratively, They argued that it encourages creativity and critical thinking. In this context, digital comics can be used to increase motivation in lessons.

Finally, in the pandemic-induced distance education process, it was concluded by the participants that in addition to developing the cognitive skills of creating digital comics, they also felt emotionally comfortable, happy, and experienced an educational process without stress and having fun. Karadağ and Yücel (2020) stated in their research that one of the areas where students experienced the lowest satisfaction in the distance education process for social sciences courses is the field of digital content / material creation. In this context, it can be said that the use of digital comics in distance education increases satisfaction

Based on the results of the research, some suggestions were made by the researchers:

1- This study was carried out with university students. Working with students at other levels can be improved.

2- The study reflects experiences of a digital educational tool. Experiences with more than one digital educational tool can be researched.

3- This digital tool can be used in other courses.

\section{References}

Anderson, T. (2011). Towards and theory of online learning. AU Press.

Apple, M., \& Kikuchi, K. (2007). Practical powerpoint group projects for the EFL classroom. The JALT CALL Journal. 3(3), 110-122. DOI: 10.29140/jaltcall.v3n3.48

Avarogullari, A. K., \& Mutlu, Z. (2019). Pre-Service social Studies Teachers' Opinions on Using Comic Books in Social Studies Teaching. Asian Journal of Education and Training, 5(4), 538-547. https://doi.org/10.20448/journal.522.2019.54.538.547

Azman, F. N., Zaibon, S. B., \& Shiratuddin, N. (2015, November). Digital storytelling tool for education: An analysis of comic authoring environments. In International Visual Informatics Conference, 347355. Springer, Cham. 
Beard, C., \& Rhodes, T. (2002). Experiential learning: Using comic strips as reflective tools in adult learning. Australian Journal of Outdoor Education, 6(2), 58-65. https://doi.org/10.1007/BF03400756

Bozkurt, A., \& Sharma, R. C. (2020). Emergency remote teaching in a time of global crisis due to CoronaVirus pandemic. Asian Journal of Distance Education, 15(1), i-vi. http://asianjde.org/ojs/index.php/AsianJDE/article/view/447

Bostan Sarığlan, A., Şen, R. \& Altaş, R. (2021). What do secondary school students think about experimental practices in science lessons taught in distance education?. Journal of Educational Technology and Online Learning, 4(2), 193-214.

Brocka, B. (1979). Comic books: In case you haven't noticed, they've changed. Media and Methods, 15(9), 30-32. https://eric.ed.gov/?id=EJ202993

Cabrera, P., Castillo, L., González, P., Quiñónez, A., \& Ochoa, C. (2013). The impact of using pixton for teaching grammar and vocabulary in the EFL Ecuadorian context. Teaching English with Technology, 18 (1), 53-76. https://files.eric.ed.gov/fulltext/EJ1170640.pdf

Creswell, J. W. (2015). Qualitative research methods: Qualitative research and research design according to five approaches (M. Bütün \& SB Demir, Trans. Ed.). Ankara: Political. Demir, Trans. Ed.). Ankara: Pegem Academy.

Efecioğlu, E. (2013). The role of graphic novels in teaching English as a foreign language. Unpublished Master's Thesis, Ankara: Hacettepe University Institute of Social Sciences.

Engler, S., Hoskins, C., \& Payne, S. (2014). Computer-produced comics as a means of summarizing academic readings in eap programs. International Journal of Pedagogies and Learning. (4),19-33 https://doi.org/10.5172/ijpl.4.4.19

Erturgut, R. (2008). Organizational, social, pedagogical and technological components of internet-based distance education. Information Technologies Journal, 1(2), 79-85. https://dergipark.org.tr/tr/download/article-file/75244

Hall, JR (2011). Books worth reading: engaging material - comics in the classroom. Change: The Magazine Of Higher Learning, 43(2), 39-43. https://doi.org/10.1080/00091383.2011.550252

Haugaard, K. (1973). Comic books: conduits to culture? The reading teacher, 27(1), 54--55. https://www.jstor.org/stable/i20193378

Hobri, H., Murtikusuma, R., \& Hermawan, L. (2019). Development of e-comic using pixton and kelase web on linear program of two variables assisted by geogebra. Journal of Physics: Conference Series. 1265. 012010. 10.1088 / 1742-6596 / 1265/1/012010.

Hosler, J. \& Boomer, K. B. (2011). Are comic books an effective way to engage nonmajors in learning and appreciating science? CBE - Life Sciences Education, 10, 309-317. https://dx.doi.org/10.1182Fcbe.10-07-0090

Hughes, J., King, A., Perkins, P., \& Fuke, V. (2011). Adolescents and "autographics": reading and writing coming-of-age graphic novels. Journal of Adolescent \& Adult Literacy, 54(8),601-610. doi:10.1598/JA AL.54.8.5

Hutchinson, K. H. (1949). An experiment in the use of comics as instructional material. Journal of Educational Sociology, 23(4), 236-245.

İlhan, G., \& Oruç, Ş. (2019). Use of comics in social studies class: Texas history. Education and Science, 44(198), 327-341. https://doi.org/10.15390/EB.2019.7830 
İlhan, G. O. (2016). Use of comics in social studies teaching. Unpublished Doctoral Thesis. Afyon: Afyon Kocatepe University Institute of Social Sciences.

Jonassen, D. (1999). Designing constructivist learning environments. In C. Reigeluth (Ed.), Instructional design theories and models: Volume II. Mahwah, NJ: Lawrence Erlbaum.

Kilickaya, F., \& Krajka, J. (2012). Can the use of web-based comic strip creation tool facilitate EFL learners' grammar and sentence writing?. British Journal of Educational, 43(6), E161-E165. doi:10.1111/j.1467-8535.2012.01298.x

Lee, V. (2013). Using Pixton as a tool in the classroom. ETEC 510 [wiki]. http://etec.ctlt.ubc.ca/510wiki/Using_Pixton_As_a_Tool_in_the_Classroom

Megawati, F., \& Anugerahwati, M. (2012). Comic strips: A study on the teaching of writing narrative texts to Indonesian EFL students. TEFLIN Journal, 23(2), 183-205.

Merriam, S. B. (2013). Qualitative research: A guide for design and practice (S. Turan, Trans. Ed.). Ankara: Nobel.

Montenegro, E., \& Yucel, C. (2020). Distance education at universities during the new type of coronavirus pandemic: an evaluation study within the scope of undergraduate students. Journal of Higher Education, 10(2), 181-192.

Olson, J. C. (2008). The comic strip as a medium for promoting science literacy. Northridge: California State University Press.

Patton, M. Q., (2014), Qualitative Research \& Evaluation Methods Integrating Theory and Practice (Fourth Edition), Sage Publications, Thousand Oaks, CA.

Richter, T., Rendigs, \& Maminirina, C. P. (2015). Conservation messages in speech bubbles - evaluation of an environmental education comic distributed in elementary schools in madagascar. Sustainability, 7, 8855-8880. https://www.mdpi.com/2071-1050/7/7/8855stats?stats=v\#

Sari, T., \& Nayır, F. (2020). Challenges in distance education during the (Covid-19) pandemic period. Qualitative Research in Education, 9(3), 328-360.

Sones, W. W. D. (1944). The comics and instructional method. Journal of Educational Sociology, 18(4), 232-240.

Topkaya, Y. (2014). The effect of using educational comics on cognitive and affective learning in citizenship and democracy education course. Unpublished Master Thesis. Erzurum: Atatürk University Institute of Educational Sciences.

Topkaya, Y., \& Şimşek, U. (2015). Impact of instructional comics on the attitudes towards citizenship and democracy education. Journal of Computer and Education Research, 3(6), 152-167. DOI: 10.18009 / jcer.26543

Ünal, O. \& Demirkaya, H. (2019). A semi-experimental study on the use of educational comics in social studies. International Journal of Geography and Geography Education. 40, 92-108. https://doi.org/10.32003/iggei.569650

Unsal, H. (2004). Various lesson models in web supported education, electronic learning and web supported education programs. Turkish Journal of Educational Sciences, 2(3), 375-388.

Vassilikopoulou, M., Retalis, S., Nezi, M. \& Boloudakis, M. (2011). Pilot use of digital educational comics in language teaching. Educational Media International, 48(2), 115-126. https://doi.org/10.1080/09523987.2011.576522

Yıldırım, A., \& Şimşek, H. (2013). Qualitative research methods in the social sciences. Ankara: Seçkin. 
Zimmerman, B. (2008). Creating comics fosters reading, writing, and creativity. Education Digest, 74(4), 55-57. 